Abant Tıp Dergisi

Olgu Sunumu / Cilt 10 Sayı 2 YII 2021
Abant Medical Journal

Case Report / Volume 10 Issue 2 Year 2021

\title{
B12 Vitamini Eksikliği Olan Göçmen Süt Çocuğu Olgusu
}

The Case of Immigrant Infant with Vitamin B12 Deficiency

Sema KÖSE ${ }^{1}$ (iD), Muharrem ÇiçEK ${ }^{1}$ (iD), Zehra ÖZTÜRK ${ }^{1}$ (i), Emel KARAOĞLAN ${ }^{1}$ (iD), Kazım ÖZTARHAN ${ }^{2}$ (D)

${ }^{1}$ Kanuni Sultan Süleyman Eğitim ve Araştırma Hastanesi, Çocuk Sağlığı ve Hastalıkları Kliniği, İstanbul, Türkiye

2 Demiroğlu Bilim Üniversitesi Tıp Fakültesi Çocuk Kardiyoloji Bilim Dalı, İstanbul, Türkiye

\section{Öz}

Çocuklarda B12 eksikliği en sık nütrisyonel alım yetersizliğine bağlı görülmektedir. Göçmen çocuklar nütrisyonel eksikliğe bağlı B12 ve D vitamini yetersizliği için yüksek risk altındadır. Bu çalışmada; ishal ve yorgunluk şikayeti ile hastanemize başvuran göçmen bir ailenin 8 aylık erkek bebeği üzerinden B12 eksikliğine dikkat çekmeyi amaçladık.

Anahtar Kelimeler: B12 Vitamini, Göçmen, Süt Çocuğu

\section{Abstract}

B12 deficiency in children is most commonly seen as a result of nutritional intake deficiency. Immigrant children are at high risk for B12 and vitamin D deficiency due to nutritional deficiency. In this study, we aimed to draw attention to the B12 deficiency from an 8-month-old male baby of a immigrant family applied to our hospital with the complaint of diarrhea and fatigue.

Keywords: Vitamin B12, Immigrant, Infant

\section{GíRiş}

İnsanlık savaşlar, yaşadıkları coğrafyadaki kötü yaşam koşulları, işsizlik ve yoksulluk nedeniyle son yıllarda göç sorunları ile karşı karşıya kalmıştır. Özellikle yaşadığımız coğrafyadaki koşulların kötüleşmesi ile ülkemiz, yarıya yakını çocuk olmak üzere 3,6 milyonu geçen göçmen ve mülteciyi misafir ederek dünyanın en fazla mülteci barındıran ülkesi durumuna gelmiştir (1). Genel olarak sığınmacılar ve mülteciler sosyal hayata uyumda zorluk ve sağlık hizmetlerine ulaşmadaki güçlükler nedeniyle sağlık açısından savunmasız gruplardandır (2). Beslenme sorunları, anemi, çocuklarda büyüme ve gelişme geriliği, kızamık, sıtma, ishal, solunum yolu enfeksiyonları, psikiyatrik bozukluklar gibi hastalıklar mültecilerde sıklıkla karşılaşılan sağlık problemleridir (3). Bulaşıı olmayan hastalıklar konusunda 2016 yılında yapılan bir çalışmanın sonuçlarına göre, 18-69 yaş aralığındaki mültecilerin $\% 58,7^{\prime}$ si yüksek risk grubunda bulunduğu raporlanmıştır (4). Yetişkinlere kıyasla büyüme ve gelişme çağında olan mülteci çocuklarda tavsiyeleri karşılamayan beslenme tarzı nedeniyle malnütrisyon, anemi, D vitamini ve B12 (kobalamin) vitamini yetersizliği için daha yüksek risk altındadırlar (5). Bu olgu sunumunda; savaş nedeni ile ülkemize göç eden, maddi yetersizlikler nedeni ile yeterli ve dengeli beslenemeyen mülteci bir ailenin ishal ve halsizlik şikayeti ile hastanemize başvuran sekiz aylık erkek bebeği üzerinden B12 eksikliğine dikkat çekilmesi amaçlanmıştır.

\section{OLGU}

Sekiz aylık altı kilogram erkek hasta üç gündür olan ishal ve halsizlik şikayeti ile hastanemize başvurdu ve genel durumunun düşkün olması nedeniyle çocuk hastalıkları servisine yatırıldı. Perinatal öyküsünde özellik yoktu. Anne ve babası arasında akraba evliliği mevcuttu. Halen anne sütü ile beslenen ve ek gıdaya geçmediği öğrenilen hastanın iştahının genel olarak az olduğu belirtildi. Hastanın ailesinin, bir yıl önce ülkemize göçmen olarak geldiği ve ekonomik nedenlerle et ve et ürünlerinin temininde zorluk yaşadıkları ve genel olarak tüketemedikleri öğrenildi. 
Fizik muayenesinde genel durumu düşkün ve çevreyle ilgisi azalmış olan hasta soluk, ikterik görünümdeydi. Turgor ve tonusu azalmış olan hastanın dilinde glossit, ağız kenarında yara, parmak uçları hiperpigmente görünüm mevcuttu. Sağ patelladan $1 \mathrm{~cm}$ yukarısında $3 \times 2$ $\mathrm{cm}^{\prime}$ lik ve karında yaygın hiperpigmentasyon saptandı. Nöromotor gelişimi yaşına göre geri olan hasta başını tutamıyor ve kas gücü tüm ekstremitelerde azalmıştı. Hastanın bu bulgular haricinde diğer sistem muayenelerinde özellik yoktu.

Hastanın bakılan tetkiklerinde lökosit 2600/ $\mu \mathrm{L}$, hemoglobin 4,8 $\mathrm{g} / \mathrm{dL}$, hematokrit $\% 14,3$, trombosit $102000 / \mu \mathrm{L}$, nötrofil $510 / \mu \mathrm{L}$, mean korpüsküler volüm (MCV) $94 \mathrm{fL}$, fosfor $2,6 \mathrm{mg} / \mathrm{dL}$, laktat dehidrogenaz (LDH) $3100 \mathrm{U} / \mathrm{L}$, haptoglobulin $0,01 \mathrm{~g} / \mathrm{L}$, total bilirubin $3,1 \mathrm{mg} / \mathrm{dL}$, direkt bilirubin $1,2 \mathrm{mg} / \mathrm{dL}$, vitamin $\mathrm{B} 12$ düzeyi $<50 \mathrm{pg} / \mathrm{mL}$, direkt coombs testi negatif, retikülosit \%1,3 saptandı. Tam idrar tetkiki, koagülasyon, kan gazı, diğer biyokimya parametreleri, folik asit, demir ve demir bağlama kapasitesi normal bulundu. Batın ve kraniyal ultrasonları normal saptandı. Çalışılan viral tetkiklerinde anti-sitomegalovirüs (CMV) IgM ve IgG pozitif olması dışında diğer sonuçlarda özellik yoktu. Hastadan CMV-DNA polimeraz zincir reaksiyon tetkiki için gönderilen kan ve idrar numunelerinde virus saptanmadı. CMV açısından yapılan göz dibi muayenesinde özellik saptanmadı. Parmak ucundan yapılan periferik yaymada trombosit kümesi yeterli olup, blast hücresi saptanmayıp, şistosit ve fragmente eritrositler görüldü.

Tedavide, $125 \mathrm{mcg} /$ gün vitamin B12 intramüsküler başlandı. Hastanın ve annesinin beslenmesi düzenlendi. Yatışında hemoglobin değeri düşük olan hastada yetmezlik bulguları gelişmesi üzerine $10 \mathrm{ml} / \mathrm{kg}^{\prime}$ dan eritrosit süspansiyonu verildi.

Hastanın annesi, babası ve altı yaşındaki kardeşinin vitamin B12 düzeyleri sırasıyla; 188 $\mathrm{pg} / \mathrm{mL}, 256 \mathrm{pg} / \mathrm{mL}$ (197-771 pg/mL) ve $276 \mathrm{pg} / \mathrm{ml}$ (245-1075 pg/mL) saptandı.

Hastanın takiplerinde LDH değerinin 3100 U/L'den $1200 \mathrm{U} / \mathrm{L}^{\prime}$ e gerilediği, retikülosit değerinin \%1,3'den \%11,2'ye yükseldiği saptandı.

Hastanın servise yatışının beşinci gününde parmak ucundan yapılan kontrol periferik yaymasında hastanın eritrosit yapısının normale döndüğü görüldü.

Hasta servise yatışının altıncı gününde dilde fasikülasyon ve yüzde kasılmanın eşlik ettiği fokal nöbetinin kontrol altına alınmasından sonra hastanın kilosuna uygun olarak klonazepam oral damla başlandı.

Hastanın takiplerinde hematokrit değerinde düşme, total bilirubin değerinde artma saptanması üzerine hasta, tedavinin devamı ve ileri tetkik için çocuk hematoloji servisi olan bir merkeze sevk edildi.

Hastanın ailesinden bilgilendirilmiş onam alınmıştır.

\section{TARTIŞMA}

Son yıllarda ülkemize savaştan ve yaşadıkları coğrafyadaki kötü koşullardan dolayı yoğun bir göç yaşanmıştır (1). Mülteci ve göçmen çocuklarda beslenme sorunları, anemi, büyüme ve gelişme geriliği sıklıkla görülebilmektedir (3). Ekim 2016'da UNICEF tarafından Türkiye'de 2200 'den fazla mülteci çocuğa yapılan beslenme taramasında 750 çocukta mikronütrisyon yetersizliği nedeniyle vitamin desteği başlandığı ve 45 çocuğun da orta derecede malnütrisyon nedeniyle tedavi programları kapsamına alındığını bildirilmiştir (6). Yapılan başka bir çalışmada ise B12 eksikliğinin Türk çocuklarına göre mülteci çocuklarında fazla görüldüğü raporlanmış ve bunun alım yetersizliğinden kaynaklandığı düşünülmüştür (5). İnsan metabolizmasında sentezlenemediği için dışarıdan alınması gereken B12 vitamininin özellikle vejetaryen olmayanlarda başlıca kaynağı 
et ve et ürünleridir. Diğer suda çözünür vitaminlerin aksine B12 vitamini, bitkiler tarafından sentezlenmez. B12 vitamini esas olarak sadece bazı bakteriler tarafından üretilmekte ve hayvanların midelerinde bulunan bu mikroorganizmalar tarafından üretilmesi ve bağırsakta absorbe edilmesi sonucunda hayvansal gıdalardaki B12 vitamininin kaynağını oluşturmaktadır. B12 vitamini, fetal ve bebek gelişiminde önemli bir rol oynar. Hayvansal kaynaklı gıda tüketiminin düşük olduğu ve perinatal desteğin yaygın olmadığı bölgelerde, bebekler B12 vitamini eksikliği riski altındadır. B12 vitamini yalnızca hayvan kaynaklı veya güçlendirilmiş gıdalarda bulunur, bu nedenle vegan beslenenlerde, düşük ve orta gelirli ülkelerdeki popülasyonlarda görülür $(7,8)$. Ülkemizde gebe kadınların \%47-72'sinde B12 vitamini eksikliği görülmektedir, bebeklerin $\% 41$ 'i de azalmış B12 vitamini depoları ile doğmaktadır $(9,10)$.

İlk altı ay sadece emzirme önerildiği için bebekler bu süre zarfında B12 vitamini için yalnızca depolarına ve anne sütüne bağımlıdır. B12 vitamini, anne sütünün normal bir bileşenidir ama annenin B12 vitamini azalmasıyla anne sütünün B12 vitamini içeriği de azalmaktadır. Gebelikte annenin B12 vitamin düzeyi, bebeğin B12 vitamin durumunu etkilemektedir. Bu bilgiler ışığında anne sütündeki B12 vitamini içeriği annenin B12 içeriği ile ilişkili olup, anne sütü ile beslenen yenidoğan ve süt çocuklarında görülen B12 eksikliği ile annenin B12 eksikliği arasında korelasyon saptanmıştır (11). B12 eksikliği olan annelerin bebekleri sadece anne sütü ile besleniyorsa ağır derecede B12 eksikliği görülebilir ve klinik belirtileri yaşamın ilk 618.ayında ortaya çıkabilir $(12,13)$. Ülkemizde Urfa yöresinde yapılan bir araştırmada, 180 gebenin $\% 72$ 'sinde, yenidoğan bebeklerin $\% 41$ 'inde; ìstanbul bölgesinde doğum yapan 250 annenin \%81,6'sında, bebeklerin \%42'sinde B12 vitaminin düşük olduğu tespit edilmiştir $(10,14)$. Klinik bulgular gelişmesi nedeniyle başvuran olgumuzun 8 aylık olması, sadece anne sütü ile beslenen olgumuzda ve annesinde vitamin B12 düzeyinin düşük saptanması bu literatür bilgilerini desteklemektedir.

Hızlı büyüme ve gelişme dönemi olan bebeklik döneminde yeterli B12 vitamini durumuna ulaşmak bebeklerde normal bilişsel gelişim için gereklidir. Doğumdan sonraki aylarda ortaya çıkabilen ancak tipik olarak 4-10 ay arası bebeklerde ortaya çıkabilen eksikliğe bağıı olarak gelişimsel gerilik ve şiddetli nöropatiye yol açabilmektedir (11). Birçok hücresel süreçte rol oynayan B12 vitamininin eksikliğinin en belirgin etkisi hematopoetik ve nörolojik sistemlerde görülürken, gastrointestinal, psikiyatrik, dermatolojik ve kardiyak bulgularla da karşılaşılabilir. Büyüme-gelişme geriliği, pansitopeni, makrositer anemi, kabızlık, ishal, nöbetler, mental motor retardasyon, aksonal dejenerasyon, apati, ciltte hiperpigmentasyon, nöropsikiyatrik değişiklikler gibi bir çok klinik durumla karşımıza gelebilir (7). İshal şikayeti ile gelen hastamızın kas tonusunda azalma, hiperpigmente cilt lezyonları, yapılan tetkiklerde makrositer aneminin eşlik ettiği pansitopeni saptanmıştır. Ayırıcı tanıda, B12 vitamin eksikliğine dair bu şikayet ve klinik tablonun, literatür bilgisi ile uyumlu olduğu görülmüştür.

Ülkemizde yapılan bir çalışmada B12 vitamin eksikliği bulunan 6-18 aylık çocuk olguların \%24,3'ünde pansitopeni saptanmıştır (12). Olgumuzda da başvuru anında pansitopeni saptanmış olup, takiplerinde yetmezlik bulgularının gelişmesi üzerine eritrosit replasman tedavisi uygulanmıştır.

B12 vitamini, merkezi sinir sisteminin gelişimi için gereklidir ve B12 vitamini eksikliği sadece birkaç hafta içinde ciddi bozulmaya neden olabilir. B12 vitamin eksikliğinin nörolojik semptomları heterojendir ve kas hipotonisi, sinirlilik, uyuşukluk, ilgisizlik, psikomotor gelişimin gerilemesi, titreme, ataksi ve nöbetleri içerir (15). Çevreyle ilgisi azalmış, nöromotor gelişimi yaşına göre geri olan olgumuz, başını tutamıyordu ve kas 
gücünün tüm ekstremitelerde azalmış olduğu görüldü. Ayrıca vitamin B12 tedavisi başlanmasına rağmen, hastaneye yatışının altıncı gününde dilde fasikülasyon ve yüzde kasılmanın eşlik ettiği fokal nöbeti olması ağır B12 vitamin eksikliğini desteklemektedir.

Sonuç olarak, sosyoekonomik nedenlerle et ve et ürünlerine ulaşımda zorluğun olduğu toplumlarda, göç ve mülteci sorunlarının yaşandığı ülkelerde vitamin ve mineral eksikliğine dair detaylı sorgulamaların ve taramaların yapılması gereklidir. Annedeki B12 vitamin düzeyi ile bağlantılı olarak anne sütündeki miktarının değişebileceği, sadece anne sütü alan bebeklerde B12 vitamin düzeyinin düşük saptanabileceği unutulmamalıdır. Vitamin replasmanlarının yapılması ile eksikliği kolaylıkla önlenebilecektir. Morbidite ve mortalitesi olan vitamin B12 eksikliğine bağlı hastalıkların önlenmesinde hastaların erken tanınması ve tedavileri önemlidir.

Bu çalışma, 9. Çocuk Dostları Kongresi'nde (16-20 Mart 2021, ístanbul) poster olarak sunulmuştur.

Bilgilendirilmiş Onam: Aileden sözlü onam alınmıştır.

Çıkar Çatışması: Yazarlar çıkar çatışması beyan etmemişlerdir.

Finansal Destek: Yazarlar finansal destek beyan etmemişlerdir.

\section{KAYNAKÇA}

1. Küçük A. Türkiye'de göç ve sağlık politikaları analizi: "sıhhat projesi" örneği. Sosyal Politika Çalışmaları Dergisi. 2020;20(47):473-96.

2. Önal A, Keklik B. Mülteci ve sığınmacıların sağlık hizmetlerine erişimde yaşadığı sorunlar: Isparta ilinde bir uygulama. Süleyman Demirel Üniversitesi Vizyoner Dergisi. 2016;7(15):132-48.

3. Yavuz Ö. Türkiye'deki suriyeli mültecilere yapılan sağlık yardımların yasal ve etik temelleri. Mustafa Kemal Üniversitesi Sosyal Bilimler Enstitüsü Dergisi. 2015;12(30):265-80.

4. Balcılar M. Health status survey of syrian refugees in turkey. Non-communicable disease risk factors surveillance among syrian refugees living in turkey.
Ministry of Health: Ankara, Turkey; 2016.

5. Yakup Ç, Özdemir AA, Alay M. Mülteci çocuklarda B12 vitamini eksikliği. Bozok Tıp Dergisi. 2020;10(1):196201.

6. Türkiye'deki Suriyeli Çocuklar Bilgi Notu [Internet]. UNICEF. 2016 [cited 28.11.2020]. Available from: https://www.unicef.org/turkey/media/5356/file/T\%C 3\%BCrkiye'deki\%20Suriyeli\%20\%C3\%87ocuklar\%20Bil gi\%20Notu\%20Ekim\%202016.pdf.

7. Rasmussen SA, Fernhoff PM, Scanlon KS. Vitamin B12 deficiency in children and adolescents. J Pediatr. 2001;138(1):10-7.

8. Arıca V, Şilfeler I, Günher Arıca $S$, Tutanç $M$, Doğan $M$, Gücük $S$. Beslenme güçlüğü ile başvuran vitamin B12 eksikliği: Olgu sunumu. İzmir Dr Behçet Uz Çocuk Hast Dergisi. 2012;2(1):44-7.

9. Halicioglu $O$, Sutcuoglu $S$, Koc F, Ozturk C, Albudak E, Colak $A$, et al. Vitamin B12 and folate statuses are associated with diet in pregnant women, but not with anthropometric measurements in term newborns. J Matern Fetal Neonatal Med. 2012;25(9):1618-21.

10. Koc A, Kocyigit A, Soran M, Demir N, Sevinc E, Erel O, et al. High frequency of maternal vitamin $B 12$ deficiency as an important cause of infantile vitamin B 12 deficiency in Sanliurfa province of Turkey. Eur J Nutr. 2006;45(5):291-7.

11. Chebaya $P$, Karakochuk CD, March KM, Chen NN, Stamm RA, Kroeun $\mathrm{H}$, et al. Correlations between maternal, breast milk, and infant vitamin B12 concentrations among mother-infant dyads in Vancouver, Canada and Prey Veng, Cambodia: an exploratory analysis. Nutrients. 2017;9(3):270.

12. Whitehead VM. Acquired and inherited disorders of cobalamin and folate in children. $\mathrm{Br} J$ Haematol. 2006;134(2):125-36.

13. Lerner NB. Megaloblastic Anemias. In: Kliegman RM, editor. Nelson textbook of pediatrics. 19th ed. USA: W.B. Saunders Co.; 2011. p. e448 - e-5.

14. Önal H, Adal E, Öner T, Önal Z, Aydın A. Gelişmekte olan ülkelerde önemli bir sorun: annede ve yenidoğanda B12 vitamini eksikliği. Türk Ped Arş. 2010;45(3):242-5.

15. Taşkesen $M$, Yaramiş $A$, Katar S, Pirinççioğlu AG, Söker $M$. Neurological presentations of nutritional vitamin B12 deficiency in 42 breastfed infants in Southeast Turkey. Turk J Med Sci. 2011;41(6):1091-6. 